УДК 159.9.07:005.963

DOI https://doi.org/10.26661/2310-4368/2021-3-5

\title{
КОМПЕТЕНТНІСНИЙ ПІДХІД ЯК МЕХАНІЗМ РЕАЛІЗАЦІЇ НЕПЕРЕРВНОГО ПРОФЕСІЙНОГО РОЗВИТКУ ЛІКАРІВ
}

\author{
Лазуренко О. О. \\ кандидат психологічних наук, дочент, \\ дочент кафедри загальної і медичної психологіі \\ Начіональний медччний університет імені О. О. Богомольия \\ бульвар Тараса Шевченка, 13, Київ, Україна \\ orcid.org/0000-0002-3540-0544, \\ elena.lazurenko@icloud.com \\ Сміла Н. В. \\ кандидат психологічних наук, \\ старший науковий співробітник лабораторії загальної психології \\ та історії психології імені В. А. Ромения \\ Інститут психології імені Г. С. Костюка \\ Національної академії педагогічних наук України \\ вулиия Панківська, 2, Київ, 01033, \\ orcid.org/0000-0001-7376-2653, \\ natalya_smelaya@merck.com
}

\begin{abstract}
Ключові слова: неперервний професійний розвиток, післядипломна підготовка лікарів, система вищзої медичної освіти, підвищення кваліфікачії, професійна компетентність, психологічна компетентність.
\end{abstract}

У статті представлено теоретичний огляд можливостей компетентнісного підходу в процесі неперервного професійного розвитку лікарів. Реалізація компетентнісного підходу в професійній підготовці фахівців у сучасних вищих медичних навчальних закладах розглядається як орієнтація на високий рівень сформованості в студентів і слухачів актуального набору компетентностей, необхідних для якісного виконання професійної діяльності. Представлено зміст етапів професіоналізації лікарів: професійне самовизначення майбутнього лікаря, урахування його професійних інтересів, нахилів; професійна підготовка студента-медика, оволодіння професійними знаннями; початок практичної діяльності, у тому числі професійне навчання в інтернатурі; виконання професійних обов'язків. Компетентність майбутнього лікаря розглядається як результат особистісної та професійної, теоретичної й практичної підготовки, володіння певним набором професійних компетенцій. Наукова новизна дослідження полягає в уточненні переліку компетенцій, які необхідні сучасному лікарю та мають знаходитися у фокусі розвитку в рамках неперервної освіти. Представлено зміст авторського курсу «Психологічна компетентність як складова професійної діяльності», який успішно впроваджується в програму неперервного професійного розвитку лікарів у Національному медичному університеті імені О.О. Богомольця. У програмі циклу висвітлено сучасний підхід до особистісно-професійного становлення фахівця медичної галузі 3 метою актуалізації професійних та особистісних ресурсів, формування систематизованих уявлень про психологічні особливості професіогенезу лікаря й сприяння розвитку його професійних компетенцій. Визначено актуальні завдання післядипломної медичної освіти. 


\title{
COMPETENCY-BASED APPROACH AS A MECHANISM FOR IMPLEMENTING LIFE-LONG PROFESSIONAL DEVELOPMENT OF DOCTORS
}

\author{
Lazurenko O. O. \\ Ph.D. in Psychology, Assistant Professor, \\ Assistant Professor at the Department of General and Medical Psychology \\ Bogomolets National Medical University \\ Taras Shevchenko Boulevard, 13, Kyiv, 01601, \\ orcid.org/0000-0002-3540-0544, \\ elena.lazurenko@icloud.com
}

\author{
Smila N. V. \\ Ph.D. in Psychology, \\ Leading Researcher at the Laboratory of General Psychology \\ and History of Psychology named after V. A. Romanets \\ National Academy of Pedagogical Sciences of Ukraine \\ G. S. Kostiyk Institute of Psychology \\ Pankivska str., 2, Kyiv, Ukraine \\ orcid.org/0000-0001-7376-2653 \\ natalya_smelaya@merck.com
}

Key words: continuous professional development, postgraduate training of doctors, system of higher medical education, advanced training, professional competence, psychological competence.
The article presents a theoretical overview of the possibilities of the competence approach in the process of continuous professional development of doctors. The implementation of the competence approach in the training of specialists in modern higher medical educational institutions is considered as an orientation to a high level of formation of students and students of the current set of competencies necessary for the quality of professional activities. The content of the stages of professionalization of doctors is presented: professional self-determination of the future doctor, taking into account his professional interests, inclinations; professional training of a medical student, mastering professional knowledge; beginning of practical activity, including professional training in internship; performance of professional duties. The competence of the future doctor is considered as a result of personal and professional, theoretical and practical training, possession of a certain set of professional competencies. The scientific novelty of the study is to clarify the list of competencies that are necessary for the modern doctor and should be in the focus of development in continuing education. The content of the author's course "Psychological competence as a component of professional activity" is presented, which is successfully implemented in the program of continuous professional development of doctors at the National Medical University named after O.O. Bogomolets. The program of the cycle highlights the modern approach to personal and professional development of a medical specialist, in order to update professional and personal resources, the formation of systematic ideas about the psychological features of the professional genesis of the doctor and promote the development of his professional competencies. The actual tasks of postgraduate medical education are determined.
Постановка проблеми. Сучасні виклики, що постають перед системою охорони здоров'я України, пов'язані з необхідністю забезпечення високого рівня якості підготовки фахівців, зумов- люють трансформацію парадигми освітнього процесу. 3 огляду на це, реалізація компетентнісного підходу в професійній підготовці майбутніх фахівців у закладах медичної освіти передбачає 
орієнтацію на високий рівень сформованості в них відповідного набору компетентностей, необхідних для якісного виконання професійної діяльності. У свою чергу, сучасні вимоги до підготовки медичних кадрів актуалізують питання про концептуальне вдосконалення системи підготовки лікарів-педагогів для вищої медичної школи. Це висуває нові вимоги до рівня професіоналізму фахівців медичного профілю, а отже, до їхньої компетентності.

Компетентнісний підхід змінив традиційну передачу знань, умінь і навичок на компетентнісну, де як критерій оцінювання результату освіти покладено рівень сформованості професійної компетентності. Психологічний складник професійної компетентності майбутнього лікаря визначальною мірою формується в процесі здобуття професійної освіти, розвивається безпосередньо в процесі професійної діяльності й вирішення конкретних фахових завдань, актуалізується в процесах професійного становлення та розвитку. Реалізація компетентнісного підходу в професійній підготовці фахівців у сучасних вищих медичних навчальних закладах передбачає орієнтацію на високий рівень сформованості в студентів і слухачів актуального набору компетентностей, необхідних для якісного виконання професійної діяльності. У зв'язку з цим у психології проблема особистості фахівця та його професійного розвитку, формування й розвитку професіоналізму, професійної компетентності $є$ важливою системною науковою проблемою.

Серед не вирішених сьогодні проблем можна виділити такі:

- невизначеність шляхів імплементації компетентнішого підходу в систему неперервної освіти лікарів (особливо післядипломної освіти);

- відсутність теоретично обгрунтованих та емпірично перевірених програм з розвитку компетентності лікарів у контексті неперервної освіти;

- відсутність єдиного переліку компетенцій лікаря, що потребують систематичного розвитку.

Мета статті - представити теоретичний аналіз можливостей компетентнісного підходу в процесі неперервного професійного розвитку лікарів.

Виклад основного матеріалу дослідження. У сучасній науці досліджуються різні аспекти запровадження компетентнісного підходу в освіті, а саме: розкриття його змісту (І. Зимня) [5], моделювання процесу формування компетентностей (С. Сисоєва) [12], формування компетентностей у майбутніх фахівців (В. Бобрицька, О. Лазуренко) $[1 ; 9]$.

Питання дослідження професійного становлення знаходяться в постійному центрі уваги багатьох учених, які визначають сутність та етапи професійного становлення (Є. Зеєр) [4], психо- логічні особливості (А. Маркова) [11], психолого-педагогічні умови й чинники професійного розвитку особистості (Л. Рибалко) [3]. Водночас низка аспектів проблеми залишається недостатньо вивченою.

Отже, проблемі післядипломної підготовки лікарів присвячено багато наукових досліджень, однак питання психологічного складника післядипломної підготовки фахівців в системі медичної освіти залишаються недостатньо вивченими $[13$, c. 104].

Професійне становлення як системне утворення починає формуватися на ранніх стадіях професіоналізації й розвивається протягом усього свідомого життя людини, що підкреслюється в провідних концепціях сучасних дослідників (А. Маркова) [11]. Аналіз сучасних труднощів у підвищенні якості професійної підготовки медиків визначив напрям і проблему дослідження. Складність вивчення цієї проблеми зумовлена наявністю великого числа різнопланових соціально-психологічних факторів, що впливають на становлення особистості лікаря й визначають ефективність професійної медичної діяльності.

Професійне становлення особистості - це цілісний динамічний процес від формування професійного самовизначення до повної реалізації себе в діяльності, що передбачає формування професійно важливих якостей. Через це, переконані, професійне становлення особистості має як освітній, так і особистісний рівні зростання [10, с. 111].

Відповідно до концепції професійного розвитку особистості, професіоналізм лікаря включає не лише ефективне виконання професійної діяльності, а й зрілість особистості фахівця, поєднання професійно важливих якостей із психологічними в процесі кваліфікованої лікувальної взаємодії.

Висока соціальна значимість медичної праці, пов'язаної з факторами дестабілізуючого впливу на особистість лікаря, з одного боку, і відсутність науково обгрунтованої системи психологічного забезпечення розвитку медика на всіх етапах його професійного й життєвого шляху -3 іншого, є тією проблемою, що зумовлює назрілу соціальну потребу визначення психологічної специфіки професійної діяльності лікаря та формування на цій основі концепції послідовного психологічного супроводу становлення особистості професіонала. Іншими словами, очевидна теоретична, методологічна та практична потреба в системному психологічному дослідженні специфіки професійної діяльності лікаря як напряму сучасної психології праці.

Професійне становлення особистості лікаря відбувається не лише під час навчання у вищому медичному навчальному закладі. Велику роль відіграють якості особистості, які розвиваються 
й удосконалюються в процесі здобуття освіти та подальшій трудовій діяльності. Професійне становлення майбутнього лікаря $\epsilon$ поетапним моментом індивідуально-особистісного розвитку фахівця.

Здійснений у попередніх дослідженнях аналіз концепцій і моделей професійно-особистісного розвитку та становлення фахівців на етапі фахової підготовки дав змогу визначити й окреслити кілька етапів професіогенезу особистості лікаря від етапу професійної психологічної готовності та адаптації до етапу професійної майстерності, джерелом якої є не лише особисті якості лікаря, а і його професійні компетенції.

Перший важливий етап - це професійне самовизначення майбутнього лікаря, урахування його професійних інтересів, нахилів. Він включає вибір професійної освіти й рівень професійної підготовки. Другий етап - це процес професійної підготовки студента-медика, оволодіння професійними знаннями. Третій етап - випускник розпочав практичну діяльність, у тому числі професійне навчання в інтернатурі. У нього $\epsilon$ можливість застосовувати набуті теоретичні знання, удосконалювати свої вміння та відпрацьовувати навички. Важливими $є$ психологічна готовність до професійної діяльності й усвідомлення професійної ідентичності майбутнім лікарем. Четвертий етап - виконання професійних обов'язків. Це період набуття власного досвіду, самостійного виконання кваліфікованої професійної діяльності, формування професійних компетентностей, власного професіоналізму, проектування кар'єрного зростання. Важливими є подальший професійний саморозвиток i самовдосконалення. П'ятий етап - висококваліфікована діяльність, професійна мобільність, професійна майстерність [7, c. 37].

В останні роки в системі професійної освіти все більше уваги приділяється компетентнісному підходу, у якому відображена прийнята в більшості розвинених країн загальна концепція освітнього стандарту, орієнтованого на формування у випускників системи загальнокультурних і професійних компетенцій. Компетентнісний підхід $€$ способом досягнення нової якості освіти. Він визначає напрям зміни освітнього процесу, пріоритети, змістовний ресурс розвитку. Різні аспекти проблеми формування професійних компетенцій глибоко й різнобічно досліджені в теорії професійної освіти, виявлені дидактичні можливості окремих навчальних дисциплін у формуванні компонентів професійної компетентності (Е. Зеер, I. А. Зимня та ін.) [4; 5].

Компетентнісний підхід дає змогу по-новому подивитися на професійну підготовку. Через освітні стандарти визначається структура компе- тенцій, які повинні бути сформовані у випускників освітньо-професійною програмою та освітньо-кваліфікаційною характеристикою, а також новітніми освітніми технологіями. За цим підходом, акцент робиться на результаті освіти, при цьому результатом $\epsilon$ не сума засвоєної студентом інформації, а здатність особистості діяти, практично вирішувати професійні завдання, вільно орієнтуватися в складних ситуаціях своєї профеciï. Саме компетентнісний підхід орієнтований на результат, тобто орієнтує освіту на формування компетентної особистості, сприяє формуванню компетентності випускника [9, с. 19].

Компетентність майбутнього лікаря - це особистісна та професійна, теоретична й практична підготовка, володіння певним набором професійних компетенцій. Іншими словами, у формуванні компетентності професіонала центральне місце має посідати організована активна, пізнавальна, самостійна діяльність кожного студента-медика, який зацікавлений пізнати «секрети професії». У свою чергу, наявність компетентностей дає змогу практично використовувати набуті в процесі навчання знання, застосовувати їх упродовж подальшої професійної діяльності, активного життя.

Для сучасної професійної підготовки майбутніх медичних кадрів актуальною є гармонічна єдність особистісного та компетентнісного підходів.

Сучасний фахівець на високому професійному рівні має володіти певними компетентностями. Так, предметна (фахова) компетентність характеризується професійними знаннями й уміннями, здатністю їх реалізовувати. Дослідницька компетентність $\epsilon$ важливою для фахівців, які уважно стежать за розвитком подій у своїй галузі та розвивають себе як науковці. Компетентність безперервного навчання включає можливість учитися і сприяти власному професійному розвитку. Соціальна компетентність передбачає наявність комунікаційних та інтеграційних здібностей, уміння підтримувати взаємини, впливати, домагатися свого, правильно сприймати й інтерпретувати думки інших, висловлювати своє ставлення тощо. Комунікативна компетентність розглядається як здатність установлювати необхідні контакти за допомогою вербальних і невербальних засобів у різних ситуаціях спілкування. Інтелектуальна компетентність виражається в здатності до аналітичного мислення і здійснення комплексного підходу до виконання обов'язків. Емоційна компетентність включає особистісні властивості фахівця: чуйність, урівноваженість, рефлексію, емпатію, толерантність тощо. Вона $€$ важливим чинником професійного становлення майбутніх фахівців. Установлено, що високий рівень саме емоційної компетентності $є$ передумовою успіху в професіях, пов'язаних з інтенсивною взаємодією з іншими людьми. 
Таким чином, сьогодні існує об'єктивна потреба у фахівцях нової формації. Отже, доречними $\epsilon$ заходи щодо оновлення освітніх технологій, перебудови професійної вищої медичної освіти, урахування досвіду соціальної практики та великий попит на професію лікаря. Підготовка майбутніх лікарів повинна набути особистісних, компетентнісних пріоритетів i включати, крім навчального процесу, певні заходи, що спрямовані на отримання практичного, професійного досвіду, формування особистості фахівця вже в процесі професійної підготовки у вищому медичному навчальному закладі [2, с. 32].

Реформування медичної галузі стосовно вищої медичної освіти передбачає якісні зміни в системі підготовки медичних кадрів шляхом підвищення кваліфікації персоналу та професійного розвитку. Такий підхід передбачає якісно нові зміни щодо організації навчального процесу, діяльності викладачів, слухачів, способів оцінювання результатів навчання на різних етапах неперервної професійної освіти, ураховуючи специфічні особливості суб' єктів післядипломної освіти тощо. Якість технології навчання у вищому медичному закладі освіти безпосередньо впливає на рівень фахової підготовки майбутніх лікарів.

Успішне формування високої професійної компетентності в майбутніх лікарів залежить не тільки від змісту освіти, а й від того, як засвоюється навчальний матеріал, які сучасні методи та технології використовуються. Важливим у цьому випадку є використання інтерактивних форм і методів навчання, що мають різноманітні ресурси, які сприятимуть здатності до саморозвитку (рефлексії, самоаналізу, самоорганізації, саморегуляції) діяльності з урахуванням індивідуально-психологічних особливостей. Зміст цих форм і методів навчання має бути побудований з урахуванням особливостей професійної діяльності, професійного досвіду, потреб та інтересів. При цьому вдосконалення професійної компетентності має здійснюватися в кілька етапів. Важливий ресурс для ефективного вдосконалення професійної, у т. ч. психологічної, компетентності становить очно-дистанційна система навчання й ті новітні інформаційно-комунікаційні технології, які можна використовувати в процесі дистанційного етапу навчання.

Удосконалення мультимедійних засобів навчання призвело до модернізації навчального процесу в цілому. Лекції читаються у вигляді презентацій, для практичних занять використовуються інтерактивні способи подання навчального матеріалу, іспити й заліки приймаються 3 використанням комп'ютерного контролю. Отже, на сучасному етапі розвитку освіти комп'ютеризація $\epsilon$ одним із перспективних напрямів активізації навчального процесу [6, с. 115].
3 огляду на пріоритетність здійснення освіти впродовж життя, а також необхідність компетентнісного розвитку лікарів і викладачів вищих медичних навчальних закладів, доцільною, на наш погляд, була б розробка програми циклу тематичного удосконалення, метою якого є отримання нових актуальних теоретичних знань і вдосконалення практичної підготовки, формування ключових професійних психологічних компетенцій, необхідних для професійної діяльності слухачів відповідно до вимог системи якості підготовки кадрів для сфери охорони здоров'я, ознайомлення 3 новітніми досягненнями в освітній галузі тощо.

Яскравим прикладом авторського бачення вдосконалення професійної психологічної компетентності фахівців медичної галузі в умовах післядипломної освіти $є$ розроблений цикл тематичного удосконалення «Психологічна компетентність як складова професійної діяльності», який успішно впроваджується в програму неперервного професійного розвитку лікарів у Національному медичному університеті імені О.О. Богомольця. У програмі циклу висвітлено сучасний підхід до особистісно-професійного становлення фахівця медичної галузі з метою актуалізації професійних та особистісних ресурсів, формування систематизованих уявлень про психологічні особливості професіогенезу лікаря і сприяння розвитку його професійних компетенцій [11, с. 126].

Завданням теоретичного курсу є висвітлення сучасного підходу до розуміння психологічної компетентності як професійно необхідної якості лікаря, складника його професійної компетентності, високого професійного рівня фахівця, що, у свою чергу, зумовлює значну потребу в іiї формуванні

Завданням практичного курсу $є$ формування психологічної компетентності фахівця задля здійснення успішної професійної діяльності, а також формування зрілої особистості та професійної ідентичності фахівця лікаря; розвиток професійної психологічної компетентності лікаря; створення умов для усвідомлення фахівцем власних професійних можливостей; формування власного професійного стилю; профілактика синдрому «професійного вигорання» медичного фахівця; усвідомлення й формування у фахівців-медиків систематизованих уявлень, теоретичних знань і практичних умінь, які дадуть змогу адекватно й ефективно застосовувати отримані знання в подальшій професійній діяльності; сприяння розвитку професійної ідентичності, професійних якостей і компетенцій лікаря; актуалізація професійних та особистих ресурсів; розвиток професійної рефлексії тощо.

Процес формування психологічної компетентності лікаря є тривалим, здійснюється на певних 
етапах професійної підготовки й потребує цілеспрямованого психолого-педагогічного впливу.

Оскільки програму циклу тематичного вдосконалення «Психологічна компетентність як складова професійної діяльності» укладено на засадах компетентнісного підходу, вона забезпечує набуття слухачами таких компетенцій таких рівнів:

- інтегральних:

- здатність розв'язувати типові та складні завдання й проблеми в певній галузі професійної діяльності або процесі навчання, що передбачає проведення досліджень i/aбо здійснення інновацій і характеризується невизначеністю умов й вимог;

- загальних:

- знання й розуміння предметної галузі й професійної діяльності та здатність застосовувати на практиці;

- особистісна прихильність до обраного фаху й мотиваційний складник щодо досягнень у фаховій діяльності;

- уміння виявляти, аналізувати, формулювати та вирішувати проблеми, що визначені особливостями галузі;

- здатність учитися й бути сучасно навченим 3 урахуванням використання новітніх інформаційних і комунікаційних технологій;

- визначеність і наполегливість щодо поставлених завдань і взятих на себе обов'язків;

- здатність адекватно оцінювати й забезпечувати якість виконуваних завдань;

- здатність до співпраці в команді, що вимагає набути навички міжособистісної взаємодії;

- здатність до вибору стратегічних засад спілкування, щоб діяти на основі етичних міркувань (мотивів), соціально відповідально та громадсько свідомо;

- здатність мотивувати людей і рухатися до спільної соціально визначеної мети;

- здатність до ведення здорового способу життя, адаптації та дії в новій (у тому рахунку конфліктній) ситуації;

- постійна включеність у процес лікувальної взаємодії, прийняття фахового рішення;

- спеціальних (фахових, предметних):

- здатність до професійного мислення на підставі аналізу та синтезу медико-психологічних знань;

- здатність застосовувати набуті психологічні знання в практичних ситуаціях, визначених особливостями галузі знань - охорона здоров'я;

- здатність установити психологічний контакт із пацієнтом;

- здатність ураховувати гендерні та вікові особливості пацієнта в процесі лікувальної взаємодії;

- здатність до практичного використання деонтологічних норм роботи лікаря 3 урахуванням гуманістичного складника, історичної спадщини та новітніх досягнень у галузі медицини;

- здатність до адекватної оцінки впливу соціально-економічних і системо-ціннісних детермінант на стан здоров'я індивідуума, сім'ї та українського соціуму в цілому;

- уміння застосовувати знання в процесі лікувальної взаємодії;

- здатність обгрунтовувати значення психологічних і педагогічних знань для майбутньої професійної діяльності;

- здатність розуміти природу та сутність психіки людини; розрізняти свідомі й несвідомі форми прояву психіки людини;

- здатність спостерігати, аналізувати, узагальнювати й систематизувати психологічні факти;

- здатність до опанування та практичного використання методів психологічної діагностики;

- здатність визначати індивідуально-психологічні відмінності особистості за їх проявами в діяльності й спілкуванні, а також ураховувати індивідуальні особливості пацієнта при обранні засобів і методів медичної допомоги;

- здатність виявляти особливості вираження емоцій і розкривати їх зв'язок з іншими психічними процесами при лікуванні захворювань;

- здатність застосовувати теоретичні знання 3 психології в повсякденному житті та професійній діяльності; формувати в собі активні позитивні риси особистості фахівця й поведінки.

На вивчення означеного циклу тематичного вдосконалення було виділено 78 годин. Форми навчання під час циклу, який триває протягом двох тижнів, відображено в навчально-тематичному плані, у реалізації концепції неперервної професійної освіти фахівців медичного профілю.

Організаційно-методичний складник розробки курсу представлено визначенням методологічної платформи, структуризацією курсу, постановкою мети й завдань. Це, у свою чергу, дало змогу спроектувати змістове наповнення практичних занять, дидактичний комплекс змістового забезпечення вивчення курсу, завдань для контрольного оцінювання знань і вмінь, а також розробити чіткі критерії й показники оцінювання результатів самостійної підготовки слухачів.

Інтерактивне спілкування в онлайн форматі $\epsilon$ необхідною умовою вивчення ефективності підвищення кваліфікації, отримання знань, умінь i компетенцій.

Висновки й перспективи подальших досліджень. Проведений теоретичний аналіз указує на те, що процес професійного становлення особистості не обмежується одним вишівським проміжком часу, він охоплює тривалий період онтогенезу людини та відбувається протягом усього іiі життя. 
Визначено, що процеси усвідомлення, становлення й зміни рівня професійного розвитку особистості відбуваються з моменту зародження професійних інтересів людини й до моменту закінчення нею професійної діяльності. Отже, актуальним завданням для післядипломної медичної освіти залишається створення персонального навчального середовища для кожного лікаря, що забезпечить можливість переходу до неперервного навчання впродовж життя.

Наукова новизна дослідження полягає в уточненні переліку компетенцій, які необхідні сучасному лікарю та мають знаходитися у фокусі розвитку в рамках неперервної освіти. Також нами запропоновано програму «Психологічна компе- тентність як складова професійної діяльності», що спрямована на розвиток психологічної компетентності лікарів і $є$ прикладом використання компетентнісного підходу в неперервній освіті лікарів.

Як найбільш перспективні напрямки подальших досліджень можна виділити:

- розробку психодіагностичних інструментів, спрямованих на визначення потреб фахівців у подальшому професійному розвитку;

- систематизацію підходів до підвищення кваліфікації лікарів 3 урахуванням здобутків компетентнісного підходу;

- експериментальну перевірку запропонованої в статті програми розвитку компетентності лікарів.

\section{ЛIТЕРАТУРА}

1. Бобрицька В. Оганізаційно-педагогічні умови формування самостійної компетенції майбутнього викладача вищої школи в умовах магістратури. Педагогічна освіта: теорія $і$ практика. Серія «Педагогіка. Психологія». 2010. № 2. С. 48-52.

2. Вежновець Т.А. Соціально-психологічне моделювання кадрового менеджменту у сфері охорони здоров'я : автореф. дис. ... докт. мед. наук : 14.02.03. Київ, 2017. 44 с.

3. Ресурсно-орієнтоване навчання студентів в умовах здоров'язбережувального освітнього середовища / М.В. Гриньова, Н.В. Кононец, М.М. Дяченко-Богун, Л.М. Рибалко. Інформачійні технології $і$ засоби навчання. 2019. Вип. 72. № 4. С. 182-193.

4. Зеер Э.Ф., Павлова А.М., Садовникова Н.О. Основы профориентологии. Москва : Высшая школа, 2005. $159 \mathrm{c}$.

5. Зимняя И.А. Педагогическая психология : учебник для вузов. Москва : Университетская книга ; Логос, 1997. 477 с.

6. Кокун О.М. Психологія професійного становлення сучасного фахівця : монографія. Київ : ДП «Інформ.-аналіт. агенство», 2012. 200 с.

7. Лазуренко О.О. Проблема саморегуляції та професійного само здійснення особистості фахівця. Теорія і практика сучасної психологї. 2018. № 3. С. 34-39.

8. Лазуренко О.О. Тенденції модернізації професійно-психологічної підготовки лікарів: компетентнісний підхід. Психологічний часопис. 2018. № 1(11). С. 87-100.

9. Лазуренко О.О., Сміла Н.В. Психологічна готовність майбутнього лікаря до професійної діяльності : навчально-методичний посібник. Київ : Інтерсервіс, 2018. 111 с.

10. Максименко С.Д. Генеза здійснення особистості. Київ : Видавництво ТОВ «КММ», 2006. 240 с.

11. Маркова А.К. Психология профессионализма. Москва : РАГС, 2006. 312 с.

12. Сисоєва С. Інтерактивні технології навчання дорослих. Навчально-методичний посібник. Київ : ВД «ЕКМО», 2011. $324 \mathrm{c.}$

13. Тертична Н.А., Лазуренко О.О. Компетентність як ціннісна орієнтація у професійній підготовці медичного психолога. Особистість та ї̈ історія : збірник матеріалів VII Міжнародної науковопрактичної конференції. Ніжин, 2017. С. 103-105.

\section{REFERENCES}

1. Bobrytska V. (2010) Ohanizatsiino-pedahohichni umovy formuvannia samostiinoi kompetentsii maibutnoho vykladacha vyshchoi shkoly $\mathrm{v}$ umovakh mahistratury [Organizational and pedagogical conditions for the formation of independent competence of the future teacher of higher education in terms of master's degree]. Pedahohichna osvita: teoriia i praktyka. Pedahohika. Psykholohiia. № 2. P. 48-52 [in Ukrainian].

2. Vezhnovets T.A. (2017) Sotsialno-psykholohichne modeliuvannia kadrovoho menedzhmentu u sferi okhorony zdorov'ya: avtoref. dys. ... d-ra med. nauk: 14.02.03 [Socio-psychological modeling of personnel management in the field of health care]. Kyiv [in Ukrainian].

3. Hrynova M.V., Kononets N.V., Diachenko-Bohun M.M., Rybalko L.M. (2019) Resursno-oriientovane navchannia studentiv $\mathrm{v}$ umovakh zdorov'iazberezhuvalnoho osvitnoho seredovyshcha [Resource-oriented learning of students in a healthy educational environment]. Informatsiini tekhnolohii i zasoby navchannia. 72, № 4. P. 182-193 [in Ukrainian]. 
4. Zeer E.F., Pavlova A.M., Sadovnykova N.O. (2005) Osnovi proforyentolohyy [Basics of professional science]. M. : Visshaia shkola [in Russian].

5. Zymniaia Y.A. Pedahohycheskaia psykholohyia (1997). Uchebnyk dlia vuzov [Pedagogical psychology. Handbook]. M. : Unyversytetskaia knyha; Lohos [in Russian].

6. Kokun O.M. (2012) Psykholohiia profesiinoho stanovlennia suchasnoho fakhivtsia: Monohrafia [Psychology of professional development of a modern specialist]. Kyiv : DP «Inform.-analit.ahenstvo» [in Ukrainian].

7. Lazurenko O.O., Smila N.V. (2018) Psykholohichna hotovnist maibutnoho likaria do profesiinoi diialnosti: navchalno-metodychnyi posibnyk [Psychological readiness of the future doctor for professional activity]. Kyiv : Interservis [in Ukrainian].

8. Lazurenko O.O. (2018) Problema samorehuliatsii ta profesiinoho amo zdiisnennia osobystosti fakhivtsia [The problem of self-regulation and professional implementation of the personality of the specialist]. Teoriia i praktyka suchasnoi psykholohii [in Ukrainian].

9. Lazurenko O.O. (2018) Tendentsii modernizatsii profesiino-psykholohichnoi pidhotovky likariv: kompetentnisnyi pidkhid [Trends in the modernization of professional and psychological training of doctors: a competency approach]. Psykholohichnyi chasopys [in Ukrainian].

10. Maksymenko S.D. (2006) Heneza zdiisnennia osobystosti [The genesis of the implementation of personality]. Kyiv : Vydavnytstvo TOV «KMM» [in Ukrainian].

11. Markova A.K. (2006) Psykholohyia professyonalyzma [Psychology of professionalism]. Moskva : RAHS [in Russian].

12. Sysoieva S. (2011) Interaktyvni tekhnolohii navchannia doroslykh. Navchalno-metodychnyi posibnyk [Interactive technologies of adult learning]. K. : VD «EKMO». 324 p. [in Ukrainian].

13. Tertychna N.A., Lazurenko O.O. (2017) Kompetentnist yak tsinnisna oriientatsiia u profesiinii pidhotovtsi medychnoho psykholoha [Competence as a value orientation in the training of a medical psychologist]. Osobystist ta yii istoriia: Zb. Materialiv VII Mizhnarodnoi naukovo-praktychnoi konferentsii. Nizhyn [in Ukrainian]. 